rapidly increased, as occurred during and after the Second World War in Britain, when production was increased about 30 per cent, and in the United States, where surpluses have piled up to the value of 6,229 million dollars by March of this year. In the food-deficit countries the main obstacle is the lack of the necessary industrial products which they are too poor to purchase. The average income in these countries is only about $£ 20$ per head-less than a tenth of what it is in Western European countries. Though the Food and Agriculture Organization, the American and the United Nations Technical Assistance Scheme, and the British Colombo Plan are doing excellent work with their limited funds, progress is too slow. Up to 1951 world population had increased by 12 per cent since the Second World War, while food supplies had increased by only 9 per cent. Owing to three good harvests, the supply per head is now about equal to what it was in 1938, but the greater part of the increase is in the already well-fed countries. In the Far East, even if targets for 1956-57 are reached, production per head will still be about 10 per cent below the 1938 level when 80 per cent of the population suffered from malnutrition and periodic hunger. It is estimated that the long-term investment of about $£ 4,000$ million a year-that is, about 10 per cent of what the world is spending on armaments-would be needed to put an end to hunger and poverty within a reasonable time.

With modern engineering and agricultural technology, to the latter of which the author of this book has made a notable contribution, it is now possible to provide sufficient food for all mankind, even though the population should grow to twice its present size. The main difficulty is the adjustment of the economic and political structure of the world to the new age of abundance which science has made possible.

BOYD-ORR

\section{A TREATISE OF GENETICS}

Traité de Génétique

Par Prof. Ph. L'Héritior. Tome 1 : le Mécanisme de l'Hérédité Génétique Formelle. Pp. iv +344. 1500 francs. Tome 2 : la Génétique des Populations. Pp. iv + 345-518. 900 francs. (Collection "Euclide" : Introduction aux Etudes scientifiques. Biologie Animale-Section dirigée par Maurice Caullery.) (Paris: Presses Universitaires de France, 1954.)

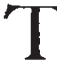

HERE is an unquestionable demand for an elementary treatise of genetics. One written by Ph. L'Héritier, who has contributed brilliantly and decisively to two fields of genetics, cannot fail to arouse expectations. The two published parts of this treatise, however, though thoughtful and informative, are somewhat disappointing in three respects. First, they lack balance between the various parts of the subject. Second, they wander repeatedly from a logical sequence in the main argument. Third, they ignore the difficulties and evolution of basic ideas such as gene, allele, ete.

For example, in Vol. 1 (the mechanism of formal genetic inheritance) a whole chapter out of a total of six deals with interspecific hybridization, a subject which has limited relevance to formal genetics. The formal genetics of Drosophila is given a share far in excess of the very large one which everybody will agree it deserves. In contrast the formal genetics of man, of Neurospora, of Aspergillus, of cotton, etc., with their distinct contributions to our ideas of mutation, segregation, organization of genes, etc., are barely mentioned, if a.t all. In Vol. 2 (genetics of populations) the treatment is prevalently theoretical, with little reference to the vast amount of experimental work on populations eithər in Nature or in the laboratory. This is the more regrettable in view of the distinctive contribution which L'Héritier himself has made to this field.

An example of disconcerting sequence in the logical development of the subject is that multiple allelism and 'pseudo' allelism are dealt with before linkage and crossing-over. An example of avoidance of the terminological and semantic difficulties is the following definition: ". . . the mendelian character is represented in the hereditary make-up by a discrete particle, called the gene..." (p. 21).

On the credit side of this treatise there is the very elementary but clear and adequate treatment of the mathematical theory of population geneties, possibly the most extensive treatment of the subject so far still comprehensible to the non-mathematician. In the first volume, linkage and mapping of the chromosome are treated in a very satisfactory and intelligible way at the elementary level. The last chrpter, on the mechanism of mutation, again gives an excellent bird's-eye view of a field which is at present rather fluid.

On the whole, it seems to the reviewer that this treatise, though useful as a reference book for people who are already well versed in the field, will not be equally useful for those who want to aequire a general balanced view of the concepts, the methods and the implications of genetics.

G. Ponteconvo

\section{PLEISTOCENE GEOLOGY AND ARCHAOLOGY OF NORTHERN FRANCE}

Les Limons Quaternaires du Bassin de La Seine Stratigraphie et Archéologie Paléolithique. (Archives de l'Institut de Paléontologie Humaine : Mémoire 26.) Par François Bordes. Pp. ii +472. (Paris: Masson et Cie, 1954.) n.p.

THIS magnificent volume of the Archives de

l'Institut de Paléontologie Humaine is of firstrate importance to all students interested in the Pleistocene geology of northern France and the succession of early Palæolithic industries in the region. In conjunction with Commont's work in the Amiens district and the volume by Georges Dubois on the Pleistocene of northern France which was published by the Société Géologique du Nord in 1924 , it gives a picture of the late geological succession in the north-eastern part of the country.

The importance of F. Bordes's new work is not so much in his conclusions but in the fact that he gives such a very large number of sections in gravel and loess pits along the River Seine from Paris to the sea and some others from neighbouring districts. Sections in the Amiens district are given to allow correlation with the work of Commont in the Somme valley. Each section has been carefully studied, and any finds, faunal or archæological, are recorded. Pages of illustrations of implements found are given. The conclusions arrived at, though clearly given, are 